\title{
MEMBACA ULANG TEKS AL-QURAN DALAM PERSPEKTIF FEMINISME SERTA PENGARUHNYA TERHADAP AKSES KEADILAN SOSIAL DI INDONESIA
}

\author{
Dian Andriasari \\ UIN Sunan Kalijaga \\ andriasaridian@gmail.com
}

Abstract: This article examines the influence of feminist discourse through the contextual approach of the holy book (Qur'an) and its influence on access to social justice. The main argument of this article states the contextualization of feminist discourse in Islam by re-reading the verses of the Qur'an which leds misogynistic in practice experiencing complexity and difficult paths. Using a feminine perspective, this article traces the interpretation of the Qur'anic text and the hadiths are detrimental to women. Therefore, "locality" is a consideration because women cannot be seen as one or monolithic. For this reason, a "locality" methodology meeting is needed in seeing the struggle of feminism in revising the authority of interpretation in an effort to make feminist studies a policy study, especially for and for the empowerment of marginal people in various parts of the world.

Keywords: qur'anic text, feminism, historical analysis, access to justice, Indonesia Abstrak: Artikel ini melihat pengaruh wacana feminisme melalui pendekatan kontekstualitas kitab suci (Alqur'an) serta pengaruhnya terhadap akses keadilan sosial. Argumen utama artikel ini menyatakan kontekstualisasi wacana feminisme dalam Islam dengan membaca ulang teks-teks ayat dalam Al-Quran yang misoginis dalam prakteksnya mengalami kompleksitas dan jalan yang tidak mudah. Menggunakan perspektif feminimse, artikel ini menelusuri tafsir teks Al-Quran dan hadits-hadits yang merugikan perempuan. Karena itu, "lokalitas" sangat menjadi pertimbangan sebab perempuan tidak 
bisa dilihat sebagai satu atau monolitik. Untuk itu perlu pertemuan metodologi yang bersifat "lokalitas" dalam melihat perjuangan feminisme dalam merevisi otoritas tafsir dalam upaya menjadikan studi feminis sebagai studi kebijakan, terutama untuk dan demi pemberdayaan kaum marginal diberbagai belahan dunia.

Kata kunci: teks Alqur'an, feminism, analisis historis, akses keadilan, Indonesia

\section{PENDAHULUAN}

Memperbincangkan spektrum wacana feminisme dan pengaruhnya dalam pranata sosial Islam, menandai dibuka kembali ruang diskursus soal-soal keadilan dan kesetaraan. Pengakuan terhadap hak-hak dasar manusia. Hal tersebut dapat pula di maknai sebagai satu upaya untuk mempertanyakan kembali tentang sejauhmana Islam memberikan kesempatan dan hak yang sama bagi perempuan untuk mengakses ruang publik. Kesempatan untuk masuk ke arena politik dan menjadi peserta demokrasi, sebagai bagian dari kesatuan sistem ekonomi, pendidikan, politik, sosial, hukum dan budaya, yang utuh. Ironisnya seringkali fakta sosial menyajikan hal yang sebaliknya, narasi yang hadir dalam ruang kehidupan masyarakat merepresentasikan wajah Islam yang cenderung diskriminatif terhadap perempuan. Legitimasi tersebut bersumber dari beberapa ayat dalam Al-Quran yang kemudian dihayati, diyakini menjadi standar dan kompas dalam kehidupan sosial.

Beberapa wacana kemudian mengemuka, salah satu diantaranya diangkat melalui kritik pemikiran oleh para pemikir muslim, yakni Amina Wadud, Fatimah Mernissi, Nawal El-Sadawi dan pemikir kontemporer lainnya yakni Fazlur Rahman dan Muhammad Syahrur yang mengemuka dengan wacananya yang cerdas mengenai teori batas. Sumbangan pemikiran mereka menjadi jalan dibukanya kembali pertarungan teori dan gagasan soal-soal keadilan dan kesetaraan bagi perempuan, yang selama ini tenggelam oleh bias paradigma klasik dalam memahami tafsir dalam Al- Quran. 
Adapun perkembangan studi perempuan menjalar ke berbagai benua di dunia ini, termasuk di negara-negara dunia ketiga. Pada tahun 1985, seorang feminis kelahiran Calcutta India, Gayatri Spivak, melontarkan sebuah pernyataan kritis, tentang apakah "Subaltern" dapat berbicara?". Subaltern ini dimaksudkan sebagai kelompok lemah yang tidak berdaya. Ketika Spivak melontarkan pertanyaan ini, para akademikus ketika itu diajak berpikir keras apakah semua pengetahuan mengenai yang tidak berdaya benar-benar berasal dari yang tidak berdaya atau hasil konstruksi dari kaum intelektual atau bahkan LSM dan kaum superior lainnya.

Spivak mendapatkan ide tentang masalah "subaltern" perempuan dari pemahamannya tentang pemikiran-pemikiran para filsuf kontemporer seperti Derrida. Dalam kasus perempuan, persoalan semakin kompleks. Seseorang yang miskin, berkulit hitam dan perempuan, mempunyai tiga beban sekaligus. Bukan saja lemah secara ekonomi, ras pinggiran dan warga negara kelas dua. Menjadi obyek karena adanya budaya patriarki yang membuat perempuan disunyikan, privilese menjadi perempuan berikut pemikiran-pemikirannya telah secara sistematis dihilangkan (Arivia, 2006: 38-39).

Saat ini di Indonesia, kajian terhadap isu-isu perempuan dan feminisme dalam ranah akademik sudah berlangsung sejak pertengahan tahun 1980-an, dengan munculnya berbagai perkuliahan mengenai isu perempuan dalam berbagai disiplin ilmu di Universitas. Para ilmuwan tidak hanya menciptakan mata kuliah baru, tetapi juga mendirikan berbagai lembaga studi dan mengembangkan berbagai kajian mengenai permasalahan yang dihadapi perempuan. Masa ini menandai babak baru sejarah masuk dan berkembangnya studi perempuan di dunia akademik. Diantaranya adalah fakultas hukum, belasan tahun kemudian sudah ada kurang lebih 23 fakultas hukum diseluruh Indonesia. Hal ini mengingatkan kita pada apa yang terjadi di Amerika pada tahun 1970-an ketika semakin banyak mahasiswa perempuan masuk sekolah-sekolah hukum. Kemudian dari kesadaran dan melalui penelitian-penelitian ilmiah melahirkan 
aliran pemikiran hukum yang disebut "feminist jurisprudence" dan "feminist legal theory".

Akan tetapi dalam perjalanannya, saat ini wacana feminisme menjadi "barang yang tidak diinginkan" tak jarang ditolak bahkan tak diinginkan keberadaannya. Komentar dan atau pernyataan negatif seringkali mewarnai arena diskusi dalam keseharian. Terdapat satu anggapan bahwa feminisme merusak tatanan akhlak perempuan sebagaimana telah digariskan dalam Al Quran dan Hadits.

Kegelisahan ini sebagaimana dipertanyakan juga oleh Judith E.Tacker sebagai seorang peneliti, ia tuliskan didalam bukunya dengan sangat baik berjudul "Women, Family, Gender in Islamic Law" sebagai berikut:

"Why would many muslim woman, and their male allies, remain steadfast in their belief that islamic principles are the fount practice, although perhaps in need of some review and revision, are the best guarentee of rights, privilages and fairness for woman. The question was further complicated, by the fact that my prior research interest, as a social historian of the Ottoman period in the Arab world, had brought me into contact with Islamic legal materials, including some of the juristic text and records of legal practice that survive from the seventeenth and the eighteenth centuries. I found it very difficult to reconcile the texture of these discussions and practice, imbued as they were by palpable concern for the rights of vulnerable members of society, the poor, the orphaned, the female-with the tone of current debates on matters like female dress and aduletry. What the relationship of the views of traditional jurits to those of the present? Are there enduring themes in the Islamic Legal position on woman and gender or do we see great variation over time? What are the basic premises of the Islamic legal constructions of women and gender and how have they been affected by historical contigencies? How have those constructions shaped and been shaped by the understandings and activities of ordinary people?"( Tucker, 2008: 1) 
Mengapa kemudian feminisme menjadi salah satu alternatif perspektif untuk memahami soal-soal akses terhadap keadilan, hal ini merupakan upaya kearah keterbukaan untuk menjelaskan posisi subordinat perempuan dalam sistem pranata sosial Islam yang selama ini dipandang diskriminatif terhadap posisi perempuan diantara hegemoni kaum patriarki. Atas dasar tersebutlah artikel ini disusun untuk mengkritisi wacana feminisme dan kontekstualisasinya dalam eksistensi Islam di Indonesia. Upaya ini menandakan bahwa manusia senantiasa berpikir dalam alur kausalitas, hal ini menandai sebagai suatu proses yang tak kenal ujung-akhir dan tak percaya lagi akan adanya apa yang disebut preestabilished order. Khusus dalam tulisan ini, penulis akan membahas beberapa permasalahan, diantaranya adalah; pertama bagaimana kontekstualisasi wacana feminisme dalam Islam dengan membaca ulang teks-teks ayat dalam Al-Quran yang misoginis, kedua bagaimana analisa historis perkembangan feminisme dan bagaimana pengaruh paradigma feminisme dalam mewujudkan akses keadilan sosial di Indonesia.

\section{KERANGKA TEORI}

Feminisme sebagai alat analisis maupun gerakan selalu bersifat historis dan kontekstual, artinya muncul sebagai jawaban atas masalah-masalah perempuan yang aktual dan kontekstual. Karena itu, "lokalitas" sangat menjadi pertimbangan sebab perempuan tidak bisa dilihat sebagai satu atau monolitik. Dalam tradisi Islam, misalnya, kaum feminis dalam kehendak untuk meningkatkan status perempuan menggunakan cara pencarian legitimasi dalam Islam itu sendiri, baik dengan melakukan penafsiran ulang ayat-ayat Al-Quran yang membicarakan soal hubungan laki-laki dan perempuan maupun dengan pencarian model-model yang ada dalam tradisi Islam awal. Vallerie J.Hoffman mencontohkan apa yang dilakukan oleh Riffat Hassan, feminis Muslim Pakistan dan Amina Wadud Muhsin soerang feminis Muslim Amerika Serikat yang keduanya menganalisis Al-Quran 
dalam upaya menjawab penafsiran-penafsiran misoginis abad pertengahan Islam (Sadawi, 2011: v).

Penjelasan antropologis tentang hubungan antara otoritas teks dan relasi kuasa dalam sebuah proses literer kompleks yang membentuk formasi wacana (discursive formation) menjelaskan signifikansi kritik beberapa sarjana terkait dengan pembaruan hukum di kalangan masyarakat muslim. Melalui kondifikasi dan pemberlakuan undang-undang pemerintah telah berusaha keras mewujudkan keadilan dan kesetaraan dalam relasi keluarga dan masyarakat. Namun, internalisasi doktrin hukum Islam yang lama (fikih), mungkin juga adat, di mana hubungan keluarga ditentukan pengaturannya berdasarkan pada kondisi dan situasi pada masa itu dan juga otoritas-otoritas yang beragam, telah membendung terealisasinya upaya rasionalisasi hukum Islam di masa sekarang ini. Di sisi lain, meskipun dalam beberapa hal telah meninggalkan paham patriarki yang menekankan pada dominasi laki-laki atas perempuan, dengan pengaruh pihak-pihak tertentu pemerintah masih menyemai dan mempertahankan konservatisme hukum.

Apa yang dilakukan Hasan dan Wadud Muhsin, sebagaimana para feminis muslim lainnya seperti Asghar Ali dan Farid Essack, merupakan kesadaran kritis untuk membangun konsep teologi Islam yang dapat membebaskan kaum perempuan dari keterkungkungan penjara budaya patriarki. Teologi feminisme Islam seperti itu sangat dibutuhkan untuk membebaskan kaum perempuan yang sudah berabad-abad telah mengalami penindasan dan diskriminasi gender. Sebab sejatinya teologi merupakan refleksi kritis agama terhadap permasalahan yang dihadapi masyarakat, maka perjuangan membangun keadilan dan kesetaraan tidak bisa dilepaskan dari bangunan teologis.

Dalam sejarahnya perjuangan feminisme terbagi kedalam tiga gelombang besar diantaranya adalah gelombang pertama yang mencakup aliran feminisme liberal, feminisme radikal, gelombang kedua mencakup feminisme eksistensial, 
gelombang ketiga mencakup feminisme postmoderen, ekofeminisme dan berbagai macam variannya.

Feminisme gelombang pertama berfokus pada isu kesenjangan politik, memperjuangkan hak pilih dimulai tahun 1792-1960an, sekitar abad 18, terrdapat tokoh Mary Wollstonecraft. Pada gelombang kedua, lebih merupakan gerakan pembebasan perempuan atau dikenal dengan woman liberation. Sebuah gerakan kolektif revolusioner, muncul tahun 1960-1980. Pada masa ini muncul sebagai reaksi kaum perempuan atas ketidakpuasannya terhadap praktik diskriminasi. Sedangkan gerakan feminisme pada gelombang ketiga dimulai dari tahun 1980 hingga saat ini. Aliran ini begitu populer, banyak tokoh feminis lahir. Isu yang dikritisi adalah mengusung keragaman dan perubahan seperti globalisasi, postkolonialisme, postrukturalisme dan postmoderenisme. Gagasan postmoderenisme mencoba melihat kembali apa yang telah dibuang, dilupakan, dianggap tidak rasional, tidak penting, ditolak, dimarginalkan dan disunyikan (Susilawati, 2017).

Gagasan postmoderenisme tersebut, kemudian direkam dalam sebuah metode untuk lebih memahami bagaimana feminisme sebagai ideologi dan alat gerakan dapat diterima. Hal itu kini terwujud dalam satu alat yang disebut "pedagogi". Pedagodi adalah jalan pikiran, sekaligus proposal kebijakan. la menuntun analisis akademis untuk menemukan lokasi politik dari ketidakadilan dalam sejarah pengetahuan dan jalinan kekuasaan. Transformasi sosial adalah tujuan dari pedagogi feminis.

Pedagogi feminis tumbuh dari kesadaran bahwa sejarah pengetahuan telah ditulis dengan pendekatan yang apolitis dan ahistoris. Tentu karena asumsi konvensional bahwa sejarah pikiran harus linier, rasional, universal, progresif dan tak terpengaruh gender16. Karena itu, "suatu pedagogi feminis" sekaligus berarti pembongkaran terhadap sejarah pengetahuan dan upaya penulisan ulang sejarah filsafat. Pengabaian atau bahkan penghapusan jejak pemikiran perempuan dalam sejarah filsafat harus dipandang sebagai skandal akademis yang memperkokoh 
institusi patriarkis. Reproduksi peralatan berpikir patriarkis itulah yang hendak dihentikan oleh pedagogi feminis. Perjuangan untuk menghasilkan cara pandang feminis itu tercermin dalam penerbitan jurnal-jurnal akademis sejak 1980-an. Claire Moses, editor feminist studies mengungkapkan:

"The emergence of a distinctive feminist academic community, in some way different from the other feminist "community", creates all kind of tensions..we know that we want to have a movement of political purpose as well as of academic purpose and not feel our lives pulled apart as we're being identified with one or another of two communities-we wish the communities were one" (McDermott, 1994: 108).

Suasana akademis tersebut terjadi di dunia barat, tiga dekade lalu. Sinisme dan hambatan universitas memperlihatkan kuatnya dominasi pendekatan ilmu yang "bebas-nilai", yang kala itu gencar dipersoalkan terutama oleh kalangan akademisi "neo-marxis" dan pascastrukturalis. Cara pandang ilmu yang bebas nilai itulah yang sesungguhnya membangkitkan kritik terhadap fungsi universitas yang kedap sosial. Pedagogi feminisme adalah bagian dari gairah ilmu sosial untuk menghubungkan pengetahuan dengan transformasi sosial (McAlister, 1996: xiii).

Kini produksi pengetahuan feminis sudah menjejakkan suatu tradisi kritik kebudayaan, analisis hukum (feminist legal studies), teori politik, epistemologi dengan satu tujuan: transformasi sosial. Sudut pandang feminis telah mencakup isu kelas, ras, wilayah, orientasi seksual, dalam upaya menjadikan studi feminis sebagai studi kebijakan, terutama untuk dan demi pemberdayaan kaum marginal. Pada pengantar edisi kedua feminist research, Hesse-Bibber sang editor, mengatakan:

"My hope is that the second edition of this handbook will provide researchers with the tool for excavating subjugated knowledge on women's lives and the lives of other marginalized groups in order to archive feminist goal of empowerment and social change"(Hesse-Biber, 2012: $x$ ). 
Pada akhirnya feminisme sebagai "isme" yang diproduksi oleh sejarah penindasan dan banalitas pikiran manusia, berbeda dengan isme produk oksiden (barat) lainnya, diskursus feminisme tidak menggunakan grand-theory yang monolitik, tunggal. Sehingga tidak ada suatu standar tunggal yang rigid dengan aplikasinya. Dengan kata lain feminisme sebagai "isme" dapat diartikulasikan secara beragam dalam konteks ruang dan waktu serta secara sosio-kultural (Gottlieb, 1993: 3). Maka dalam hal ini penulis mengajukan satu asumsi dan dapat dimaknai; apabila sepanjang suatu pemikiran, dan gerakan, berangkat dari kesadaran tentang terjadinya penindasan baik fisik maupun mental terhadap perempuan dan atau masyarakat, sehingga kesadaran akan pentingnya membuka akses keadilan dan kesetaraan menjadi motor penggerak untuk dengan sengaja dan sadar mengubah keadaan tersebut

\section{KOMPLEKSITAS KEDUDUKAN PEREMPUAN DALAM ISLAM}

Apakah mungkin Islam dan feminisme seiring sejalan? Atau pertanyaan lainnya adalah apakah feminisme tidak sesuai dengan ajaran Islam? Bagaimana Islam dapat mengakomodasi perspektif berpikir dan feminisme sebagai ideologi yang menurut sebagai banyak masyarakat bersumber dari pemikir-pemikir barat dan sangat bertentangan dengan Islam (Al-Quran dan Hadis).

Padahal terdapat beberapa pemkir kontemporer muslim seperti Muhammad Syahrur yang menawarkan alternatif pemikiran yakni aplikasi fiqih baru dalam studi permasalahan perempuan dam Islam. la memiliki anggapan bahwa apa yang telah dihasilkan pada masa Nabi Saw tentang hak-hak perempuan atau dengan ungkapan lain usaha pembebasan posisi perempuan bermula dari awal diutusnya Nabi Saw dan belum berakhir setelah beliau wafat. Konsekuensinya, jika para perempuan pada zaman Nabi tidak ada yang bekerja di luar rumah atau tidak ada yang memiliki jabatan politik, hal demikian tidak lantas dipahami sebagai bentuk larangan bagi perempuan untuk beraktifitas di ranah publik. Maka struktur berpikir demikian merupakan sarana untuk transformasi 
sosial yang diperjuangkan oleh para kaum feminis, yang berusaha untuk melihat kembali posisi perempuan dalam Islam saat ini.

Pendapat lainnya mengenai feminisme dalam Islam juga dikemukakan oleh Badran dalam bukunya "Feminisme dalam Islam" ia menjelaskan; "Islamic feminism' as "a feminist discourse and practice articulated within an Islamic paradigm. Islamic feminism, which derives its understanding and mandate from the Qur'an, seeks rights and justice for women, and for men, in the totality of their existence (weekely.ahram.org. eg, 2002, no. 569).

Persoalan status perempuan dalam studi Islam sampai sekarang masih tetap menjadi isu menarik dan penting di bahas. Sebab sikap dan praktek kaum muslim terhadap kaum wanita hampir sepanjang sejarah kaum muslimin, menurut sejumlah ilmuwan, tidak sejalan dengan salah satu pesan dan misi pokok yang diperjuangkan Nabi Muhammad dengan agama Islam yang dibawanya. Fakta sejarah membuktikan sebaliknya, bahwa hampir sepanjang sejarah muslim, kaum wanita ditempatkan pada posisi inferior sementara laki-laki berada pada posisi superior. Padahal Al-Quran menempatkan posisi wanita sejajar dengan laki-laki (Nasution, 2002: 1).

Bahwa salah satu misi pokok Al-Quran tentang perempuan adalah memposisikannya sejajar dengan laki-laki. Ada sejumlah Nash yang dapat dicatat untuk menunjukkan pandangan ini. Diantaranya dan merupakan indikator pertama adalah, ayat Al-Quran yang secara tegas menyebut bahwa perempuan dan laki-laki adalah sejajar seperti disebutkan dalam Al-Baqarah (2) 187, 228 bahwa asal-usul manusia laki-laki dan perempuan adalah satu (jiwa yang satu) seperti disebutkan dalam An-Nisa (4);1, Al-Hujurat (49):13 bahwa laki-laki dan perempuan mendapat ganjaran yang sama dari amal pekerjaan (baik atau buruk).

Al-Quran melawan segala bentuk ketidakadilan, seperti eksploitasi ekonomi, penindasan politik, dominasi budaya, dominasi gender, dan segala corak disequilibrium dan aprtheid. Tampak dengan jelas, bahwa ayat-ayat Makkiyah khususnya lebih menekankan pada masalah keadilan sosial. Seperti misalnya 
digambarkan dalam surah al-Ma' un (107):1-7, Nabi begitu tekun dan bersemangat memperjuangkan struktur masyarakat Mekkah yang kapitalistik dan feodalistik menuju masyarakat yang adil dan egalitarian (Nasution, 2002: 2).

Terkait hal ini, Syahrur berpandangan bahwa pembebasan posisi perempuan dalam Islam dapat dilihat dalam kasus perbudakan. Dalam kasus yang cukup sensitif ini Islam tidak melakukan perombakan secara frontal karena dapat menyebabkan hancurnya tatanan masyarakat. Yang ditempuh kemudian oleh Islam adalah peletakan dasar-dasar/prinsip-prinsip pemecahan masalah dalam alKitab yang dapat dikembangkan lebih lanjut sesuai perkembangan zaman dalam sejarah. Dalam konteks ini, masalah perbudakan memberikan informasi paling jelas bagaimana hukum disampaikan secara bertahap dalam masyarakat Islam (Syahrur, 2007: 229).

\section{FEMINISME SEBAGAI SUATU STUDI KRITIS}

Gerakan feminisme Islam (harakah tahrir al-mar'ah) dalam sejarah Islam sendiri, khususnya di Indonesia, berlangsung dalam beberapa cara. Diantanya adalah melalui pemberdayaan terhadap kaum perempuan, yang dilakukan melalui pembentukan pusat studi wanita di perguruan-perguruan tinggi, pelatihanpelatihan dan training-training gender, melalui seminar-seminar maupun konsultasi-konsultasi. Kegiatan seperti ini biasanya dilakukan oleh lembagalembaga swadaya masyarakat (LSM) yang memiliki konsen dengan persoalanpersoalan keperempuanan, seperti P3M (Perhimpunan Pengembangan Pesantren dan Masyarakat), Rifka An-Nisa WCC (Woman Crisis Centre), Yasanti (Yayasan Annisa Swasti) dan lain-lain. Selain itu, lembaga-lembaga dalam konsen ini juga dikenal dalam mengkritisi kebijakan-kebijakan Negara yang dinilai merugikan keberadaan perempuan (Surorini, 2012: 25).

Pada bagian ini penulis akan menguraikan Feminisme dan perkembangannya sebagai studi kritis terhadap realitas sosial. Menurut Maggie Humm feminisme adalah ideologi pembebasan perempuan karena yang melekat 
dalam semua pendekatannya adalah keyakinan bahwa perempuan mengalami ketidakadilan disebabkan jenis kelamin yang dimilikinya. Feminisme juga dapat dimaknai sebagai himpunan teori, gerakan politik dan falsafah moral yang sebagian besarnya didorong oleh atau berkenaan dengan pembebasan perempuan daripada pengetepian oleh kaum lelaki (Hidayatullah, 2010: 6).

Diskursus tentang kaum perempuan dan kedudukannya dalam kehidupan sosial selalu menjadi topik yang menarik. Dalam struktur sosial yang berkembang di masyarakat perempuan ditempatkan di dalam posisi minoritas. Apalagi dalam masyarakat yang secara umum bersifat patrilineal yang berarti memuliakan kaum lelaki dalam semua aspek kehidupan. Dalam perkembangan penelitian dengan kerangka pemikiran Feminisme, muncul tantangan yang dihadapi dalam penelitian kualitatif kaum feminis. Sehingga perlu memetakan ruang lingkup penelitian, model penelitian yang jelas, dan isu-isu yang dihadapi para peneliti feminis. Apapun gaya penelitian kualitatif dan secara sadar didefinisikan sebagai feminis atau tidak yang pasti bahwa problematika kaum perempuan adalah sesuatu yang penting untuk diteliti pada kerangka teoritis, kebijakan, atau tindakan demi merealisasikan keadilan sosial bagi kaum perempuan (Umar, 1999: 73-76).

Feminisme sebagai "ruh" dari gerakan, pertama kali muncul di Eropa dari abad ke-17 pada awalnya merupakan bentuk protes dari kaum perempuan terhadap gereja. Pada masa itu, gereja merupakan institusi tertinggi yang menguasai hampir seluruh aspek kehidupan masyarakat. Pada dasarnya kekuasaan gereja yang terlalu besar dan aturan-aturannya yang bersifat mutlak memang dianggap sewenang-wenang dan menyusahkan masyarakat pada umumnya. Akan tetapi, kaum perempuan sebagai kelompok minoritas bahkan menerima perlakuan yang lebih tidak menyenangkan lagi karena mereka dianggap sebagai makhluk golongan kedua setelah lelaki. Berbicara mengenai akar historis perkembangan feminisme di dunia, maka tidak dapat dilepaskan dari sejarah gerakan feminisme modern yang dimulai pada tahun 1960 dan dipelopori oleh 
kaum perempuan intelektual di Amerika Serikat. Pada gerakan feminisme modern tersebut kaum perempuan memperjuangkan hak-hak sipil perempuan dalam masyarakat, pendidikan dan juga politik. Tokoh-tokoh yang paling popular pada saat itu diantaranya Virginia Woolf dan Charlotte Perkins.

Selanjutnya pada tahun 1970-an, masih di Amerika Serikat, muncul suatu gerakan feminisme yang kemudian dikenal sebagai feminisme radikal karena memiliki landasan teori dan tujuan sendiri yang tidak berdasarkan teori Marxis. Para aktifis feminisme radikal memperjuangkan pengembangan epistemologi yang berperspektif feminis, sehingga kajian women's studies dapat diterima oleh kalangan akademisi lain. Sedangkan di Indonesia, pasca Kartini mewacanakan kesetaraan hak-hak perempuan, maka periodisasi selanjutnya ruang diskursus itu bergulir hingga pascakemerdekaan, spektrum perjuangan perempuan terlihat lebih kongkrit yakni merambah pada dunia akademis.

Pemikiran Gayarti Spivak sebagaimana telah penulis paparkan pada bagian pendahuluan merupakan langkah awal mempertanyakan kembali bagiamana jejak feminisme dalam akar sejarah sejak masa postkolonial. Narasi sejarah perjuangan Kartini menjadi penting untuk ditelusuri apakah peran dan pengaruhnya pada zamannya saat itu dan bagaimana pengaruhnya hingga saat ini pada era postmoderen. Teori feminis dan postkolonial memulai dengan usaha untuk melihat keterkaitan antara gender/budaya/etnisitas dengan cara menolak oposisi biner yang menjadi dasar dari otoritas patriarkal dan kolonial. Teori oposisi biner ini telah banyak dikemukakan oleh feminis Perancis Helene Cixous. la adalah seorang novelis yang mengontraskan gaya menulis perempuan dan gaya menulis laki-laki.

Teoritikus postkolonial melihat cara berpikir dikotomik yang kental mendiskriminasikan wacana dan budaya lokal. Pendiskriminasian ini dipicu lewat kondisi-kondisi imperialis. Dalam wacana feminis, bahwa dalam dunia ketiga terdapat "kolonialisasi ganda" adanya kontras antara ketidakmatangan politik dunia ketiga dengan etos progresif feminisme barat. Jadi representasi perempuan 
dunia ketiga sebagai yang bodoh, miskin, tidak terdidik, terikat tradisi, terdomestikasi, orientasi keluarga tradisional dan korban. Sedangkan representasi perempuan barat sebagai pintar, mapan, terdidik, punya pilihan bebas dan moderen (Umar, 1999: 76).

Feminisme memiliki pengertian yang berbeda dengan kesetaraan gender, seperti yang dikemukakan oleh Mansour Fakih, bahwa yang dimaksud dengan gender adalah suatu sifat yang melekat secara sosial maupun kultural. Misalnya perempuan dikenal lemah lembut, cantik, emosional dan keibuan sedangkan lakilaki dianggap kuat, rasional jantan dan perkasa. Sifat-sifat tersebut sebenarnya dapat dipertukarkan artinya ada laki-laki yang memiliki sifat emosional, lemah lembut dan keibuan dan juga ada perempuan yang kuat, rasional dan perkasa. Jadi seks bersifat kodrati dan gender bersifat non kodrati. Penggunaan istilah gender dalam makna tersebut mulai sering digunakan di awal tahun 1077, ketika sekelompok feminis di London tidak lagi memakai isu-isu lama seperti patraiarchal atau sexist, tetapi menggantinya dengan wacana gender (gender discourse) (Fakih, 1997: 8-9).

Kerangka analisis dengan menggunakan perspektif feminisme, dijelaskan secara terperinci dalam buku Handbook of Qualitative Research dijelaskan bahwa ruang lingkup penelitian Feminis kualitatif adalah sebagai berikut (Denzin dan Lincoln, 1994: 161- 162):

1. Subyektivitas, meskipun orang beranggapan bahwa penelitian feminis kualitatif akan memfokuskan diri pada subyektifitas dan hubungan antar pribadi, asumsi ini mencerminkan kelemahan kritik yang menyatakan bahwa penelitian kualitatif tidak dapat memecahkan struktur atau isu-isu yang lebih besar. Karena sesungguhnya penelitian feminis saat ini mencakup dan melampaui seluruh level ini dan memanfaatkan sepenuhnya berbagai metode kualitatif. Sebagaimana penelitian yang dilakukan terhadap subyektivitas dan pengalaman kaum perempuan dalam bidang kesehatan dengan menerapkan teknik wawancara terhadap sejumlah 
pasien perempuan yang tidak menuruti anjuran dokter. Ternyata mereka kaum perempuan bukanlah orang-orang yang sulit diatur dan selalu membantah, tapi mereka ternyata memiliki alasan yang rasional.

2. Hubungan dan Interaksi, penelitian feminis kualitatif di sini meliputi hubungan dan interaksi antar personal (hubungan dan interaksi antara lakilaki dan perempuan) ataupun hubungan dan interaksi sosial yang lebih luas yang berkaitan dengan tugas dan pekerjaan mereka.

3. Gerakan, Organisasi, dan Struktur Sosial, Ruang lingkup penelitian ini meliputi gerakan dan organisasi sosial, pergerakan yang menyangkut ras, kelas sosial, dan orientasi seksual yang berusaha untuk menjembatani antara kajian mikrointeraksional dengan penelitian makrointeraksional yang mencermati unit-unit sosiologis makro/ masyarakat yang lebih luas. Penelitian ini mengacu kepada analsisi struktur yaitu tentang bagaimana masyarakat dan kelembagaan berbaur dengan aktivitas manusia.

4. Kebijakan, hal ini mencakup tinjauan ulang terhadap analisis kualitatif kebijakan. Meskipun penelitian feminis kualitatif tidak banyak berdampak terhadap para pembuat kebijakan. Seperti penelitian tentang perdebatan seputar aborsi dan alasan munculnya sindrom pra menstruasi sebagai masalah sosial.

Sedangkan dalam ranah ideologi, feminisme masuk ke dalam kajian-kajian agama terhadap persoalan-persoalan yang bersentuhan dengan perempuan. Wacana ini lahir berdasarkan tuduhan adanya hegemoni Islam terhadap perempuan muslim di negara-negara Islam. Sehingga terkesan membatasi ruang gerak dinamis perempuan dan mendiskriminasikan posisi perempuan di dalam masyarakat, bahkan terkadang aspirasi dan suara hatinya tak didengarkan.

Sangat mungkin sekali bahwa feminisme dalam Islam memilki koherensi feminisme yang bersumber dari ajaran Islam yaitu al-Quran dan Sunnah, yang secara komprehensif telah memaparkan kesamaan hak asasi antara perempuan dan laki-laki meliputi hak beribadah, keyakinan, potensi dan pendidikan tanpa 
mengingkari adanya tamayyuz secara fitrah antara keduanya. Bahkan Al-quran memuliakan perempuan dengan kehadiran satu surat khusus di antara 114 surat yang ada di dalamnya yaitu surat Al-nisa (Karim, 2014: 62).

Dengan kata lain, feminisme merupakan kepercayaan kepada kesetaraan dalam ranah sosial, politik dan ekonomi antara kedua jenis kelamin, pria dan wanita. Feminisme juga diarahkan kepada sebuah gerakan yang dikendalikan berdasarkan keyakinan bahwa kedua jenis kelamin tersebut harus tidak merupakan faktor penentu yang membentuk identitas sosial atau hak-hak sosiopolitik dan ekonomi seseorang.

Sebagaimana ungkapan De Beauvoir dengan menafsir ulang bahwa dasar seorang "manusia Descartes" adalah dasar yang memiliki kekuasaan cogito yang didasarkan seluruhnya pada I (I think) yang mampu menyelesaikan segala hal. Sedangkan manusia perempuan tidak memiliki kekuasaan cogito melainkan keraguan (atau diragukan?) identitas seksnya, karena ia didefinisikan sebagai perempuan oleh masyarakat. Oleh sebab itu, bila Descartes mendefinisikan manusia sebagai I think therefore I am, bagi perempuan I am a woman, there-from I think. Dengan menjawab I am a woman dan bukan I think, de Beauvoir sadar bahwa I am bagi perempuan selalu berimplikasi pada apa yang didefinisikan orang/masyarakat yang bukan mengacu atau berdasarkan pada fakta pemikiran perempuan melainkan pada fakta biologis perempuan. Maka, de Beauvoir berketetapan bahwa, "One is not born, but rather becomes, a woman" (Arivia, 2013: 29-30).

Pemikiran filosofis de Beauvoir yang dituangkannya dalam buku The Second Sex (1949) memang berangkat dari pemahaman keseharian, apa yang disebut menjadi seorang perempuan yang berangkat dari situasi konkret dan bukan abstrak. Memang karya filosofis yang berangkat dari kekhususan situasi sempat diragukan dan dianggap kurang filosofis, namun filsuf feminis seperti Carol C. Gould secara gigih berargumentasi bahwa pertanyaan tentang perempuan adalah pertanyaan filosofis. Ada beberapa pendekatan dalam menghadapi soal ini. 
Pertama, perempuan seperti laki-laki adalah manusia dengan demikian hakhaknya universal. Kedua, sesungguhnya tidak ada manusia yang universal, yang ada adalah adanya kodrat laki-laki dan kodrat perempuan dan bila kodrat laki-laki dapat dipertanyakan secara filosofis, kodrat perempuan sama halnya. Gould menunjukkan bahwa pendekatan kedua berarti membahas perbedaan antara lakilaki dan perempuan yang ditinjau dari sejarah, sosial, dan budaya dan bila ditilik lebih lanjut perbedaan tersebut melahirkan penindasan, dengan demikian keseluruhan hal tersebut sangat erat kaitannya dan mengakar pada persoalan filsafat.

Beralih pada perkembangan feminisme sebagai ideologi dan alat gerakan, di negara-negara Timur Tengah, mengalami kecenderungan perkembangan yang sulit. Kuatnya tradisi agama dalam mengatur tata kehidupan masyarakat, pada akhirnya hanya menyediakan ruang gerak yang sangat sedikit bagi perempuan untuk bergerak, terlibat langsung dalam ranah sosial, politik dan ekonomi, hukum serta budaya. Domestikasi peran perempuan sangat terasa kental.

Sebagai contoh soal penindasan terhadap perempuan, eskploitasi dan tekanan sosial yang dialami, tidak dapat serta-merta diidentifikasi sebagai ciri masyarakat Arab atau masyarakat Timur Tengah atau negara-negara "Dunia Ketiga" saja. Akan tetapi dalam narasi sejarah bagaimana tradisi perbudakan masih terjadi. Akan tetapi realitas itu semua merupakan bagian integral dari sistem politik, ekonomi dan budaya yang berpengaruh besar dalam hampir seluruh dunia, baik sistem itu melingkupi masyarakat terbelakang dan masih bersifat feodal atau yang mewarnai masyarakat industri moderen yang menyerah kepada revolusi sains dan teknologi (Sadawi, 2011: v).

Banyak pengamat dan analis melakukan kajian terhadap praktik peradilan di berbagai negara muslim untuk melihat apakah hukum Islam yang diadopsi dan dikembangkan negara memengaruhi wacana dan praktik hukum masyarakat. Faktanya, meski kodifikasi hukum yang diperkenalkan oleh pemerintah di berbagai negara Muslim umumnya mengambil doktrin-doktrin Islam klasik, 
khususnya doktrin kitab-kitab fikih yang dianut oleh masyarakatnya, seperti Syafi'i di Indonesia dan Maliki di Maroko, kompilasi hukum Islam memperkenalkan sejumlah aspek pembaruan. Aspek-aspek ini mencakup dipertimbangkannya adat-istiadat setempat, kepentingan negara, dan normanorma baru yang berkembang dalam masyarakat. Léon Buskens, guru besar hukum Islam Universitas Utrecht dan Leiden Belanda, memetakan hubungan antara syariah, hukum negara, dan adat setempat, yang dia jadikan basis bagi teori "model segitiga" (triangular model). Dengan membangun model semacam ini, dia ingin menunjukkan bahwa selain syariah, norma-norma yang terkait dengan hukum egara dan adat-istiadat setempat sangat penting untuk memahami keragaman norma yang menata perilaku umat Islam.

Islam telah mengangkat derajat kaum perempuan, sesuatu yang belum pernah diberikan oleh peradaban sebelum Islam seperti peradaban Yunani, Romawi, Arab jahiliyah, agama Nasrani dan Hindu. Lebih parah lagi sejarah Eropa dan Inggris telah menempatkan perempuan pada kasta terendah di tatanan masyarakat mereka. Meski demikian hal-hal ini tetap tidak bisa membebaskan Islam dari pandangan negatif Barat tentang aturanaturan Islam yang mereka anggap kaku dan menjerat perempuan dalam mata rantai tugas-tugas rumah tangga saja. Tidak hanya itu, mereka juga menyorot terjadinya kasus tindak kekerasan yang menimpa perempuan, kecilnya ruang partisipasi perempuan di sektor politik dan publik. Ditambah lagi dengan himpitan kenyataan nasib kaum perempuan di banyak negara yang secara realitas mewakili dunia Islam seperti Saudi Arabia, Sudan, Pakistan, Bangladesh dan lain sebagainya (Karim, 2014).

\section{FEMINISME ISLAM DAN AKSES KEADILAN SOSIAL DI INDONESIA}

Kehidupan sosial sangat berpengaruh pada pembentukan paradigma berpikir seorang manusia. Bourdieu mendefinisikan kehidupan sosial sebagai interaksi struktur, kecenderungan, dan tindakan saling mempengaruhi antar manusia dalam melaksanakan praktik sosial masing-masing. Praktik sosial itu sendiri 
merupakan hasil proses improvisasi yang distrukturkan oleh orientasi budaya, sejarah perorangan, dan kemampuan untuk berperan dalam interaksi sosial. Di Indonesia, narasi yang patriarki dibangun oleh elemen budaya, sejarah, politik dan dibuat oleh penguasa. Itu sebabnya memutus mata rantau ketidakadilan terhadap perempuan merupakan suatu hal yang sulit. Kecenderungan ini juga terjadi di negara-negara dunia ketiga.

Memotret ketidakadilan terhadap perempuan, dapat dengan mudah diakses, menurut data yang diperoleh dari catatan Tahunan Komnas Perempuan tahun 2018 terdapat 348.446 kasus kekerasan terhadap perempuan yang dilaporkan dan ditangani selama tahun 2017, yang terdiri dari 335.062 kasus bersumber pada data kasus/perkara yang ditangani oleh Pengadilan Agama, serta 13.384 kasus yang ditangani oleh 237 lembaga mitra pengadalayanan, tersebar di 34 Provinsi. Komnas Perempuan mengirimkan 751 lembar formulir kepada lembaga mitra pengadalayanan di seluruh Indonesia dengan tingkat respon pengembalian mencapai 32\%, yaitu 237 formulir.

Menurut para feminis, yang dimaksudkan dengan keadilan antara laki-laki dan perempuan adalah kesetaraan hak dan kewajiban diantara mereka. Bagi para feminis laki-laki dan perempuan tidaklah berbeda kecuali dari sisi biologis saja, dimana perempuan bisa mengalami menstruasi, mengandung, melahirkan dan menyusui, sementara laki-laki tidak. Inilah yang disebut dengan kodrat perempuan, yang berbeda dengan kodrat laki-laki. Selebihnya, perbedanperbedaan lain yang terjadi pada laki-laki dan perempuan hanya terjadi akibat konstruksi sosio-kultural saja. Perbedaan biologis, dengan demikian sama sekali tidak berarti ketidakseteraan dalam status jenis kelamin secara sosial. Fungsifungsi biologis tidaklah sama, dan memang harus dibedakan, dengan fungsi-fungsi sosial (Engineer, 1994: 59).

Studi perempuan dalam Islam dikategorikan sebagai salah satu tema yang sangat sensitif, yang menarik perhatian para pembela dan para musuh Islam untuk mengkajinya bermula sejak zaman kebangkitan (sekitar tahun 70-an) hingga saat 
ini. Meskipun dalam hal ini Syahrur kurang yakin bahwa saat ini telah hadir sebuah kajian yang otentik dan komprehensif tentang perempuan dalam Islam yang berangkat dari hubungan dialektis antara karakter dasar Islam, yaitu istiqamah dan hanifiyyah dan karakter dasar manusia, yaitu fitrah yang serasi dengan hukum-hukum alam, serta kajian yang menjadikan batas-batas hukum Tuhan sebagai tulang punggung pijakannya (Syahrur 2007: 226).

Para pembela Islam mendasarkan kajian mereka tentang tema perempuan ini semata-mata pada perspektif fiqih. Mereka beranggapan bahwa produkproduk hukum lima madzhab fiqih adalah produk pemikiran yang valid dan adil bagi perempuan. Sementara itu, para musuh Islam berangkat dari sumber-sumber di luar Islam untuk memberikan solusi atas masalah perempuan. Dalam beberapa kasus, bisa saja tawaran solusi mereka sesuai dengan prinsip-prinsip Islam tanpa mereka sadari. Problem perempuan abad moderen tidak dapat diselesaikan tanpa melibatkan konsep Islam tentang perempuan yang otentik dan orisinal yang bersumber dari batasan-batasan hukum Tuhan dalam al-Kitab dan dalam konsep kontemporer tentang Sunnah.

Spektrum isu-isu perempuan (gender) kemudian akan dilihat dalam konstruksi-konstruksi gender/seks oleh media, agama, budaya dan negara akan diidentifikasi, khususnya yang cenderung mengorbankan/mendiskriminasi kelompok warga negara tertentu, seperti perempuan. Keterbatasan akses, KDRT, sexual harassment, poligami, human trafficking, dan lain-lain adalah contohcontoh kasus yang dapat dianalisis untuk merefleksikan dampak-dampak konstruksi gender/seks dalam konteks penundukan tetapi seringkali dianggap normal.

Isu yang digulirkan dalam pewacanaan feminisme saat ini masih menyoal reaksi atas perubahan sosial, politik dan ekonomi juga masalah hukum. Persoalan keterwakilan politik perempuan, kemiskinan, kebutuhan kesehatan reproduksi perempuan. Disamping persoalan tersebut isu pekerja migran yang menyisakan potret eksploitasi perempuan. Sebagai contoh, perempuan yang karena peran 
gendernya telah dimarjinalkan di sektor domestik, menjadi semakin terpuruk karena kerja domestik sama sekali tidak dianggap bernilai dan karenanya dianggap bukan pekerjaan dan tidak terlindungi. Meski konvensi ILO No.189 tentang Kerja Layak bagi Pekerja Rumah Tangga dan Rekomendasi ILO No.201 yang melengkapinya telah dikeluarkan, saat ini negara Indonesia belum secara eksplisit mengakui keberadaan pekerjaan kerumahtanggaan sebagai pekerja.

Bagaimanapun juga penguatan kemampuan dan persamaan hak berdasarkan pada sensitivitas gender di tengah-tengah masyarakat masihlah menjadi masalah utama dalam masyarakat. Meskipun intensifikasi permasalahan perempuan dan gerakan pendukung hak-hak perempuan di seluruh dunia telah direfleksikan melalui berbagai macam konvensi yang telah dikeluarkan oleh Perserikatan Bangsa-Bangsa. Beberapa perlindungan yang diakui secara internasional tersebut telah membantu mengartikulasikan ideologi dari para kaum pejuang hak perempuan.

Keadilan gender seringkali tidak memperoleh tempat khusus pada ketentuan konstitusi di dalam hal persamaan hak di hadapan hukum atau persamaan dalam perlindungan hukum. Hal tersebut terjadi disebabkan persamaan hak kurang dipahami secara menyeluruh dan hal itu diperparah ketika kebijakan negara tidak mengakomodasi bahwa antara laki-laki dan perempuan mempunyai kedudukan dan derajat yang sama.

Sebagai contoh dalam perkembangan demokrasi di Indonesia saat ini menunjukkan bahwa perempuan turut mewarnai perhelatan pilkada serentak 2018 yang pemungutan suaranya akan digelar pada 27 Juni 2018 mendatang, baik di tingkat provinsi maupun kabupaten/kota. Berdasarkan data Komisi Pemilihan Umum, sebanyak 101 perempuan menjadi kandidat dalam pilkada tersebut. Sebanyak 49 perempuan maju sebagai bakal calon kepala daerah dan 52 lainnya terdaftar sebagai bakal calon wakil kepala daerah. Jumlah kandidat perempuan di pilkada mendatang adalah 8,8 persen dari total 574 pasangan bakal calon kepala daerah dan wakil kepala daerah terdaftar. Jumlah tersebut merupakan 
peningkatan. Pasalnya, pada pilkada serentak 2015 terdapat 7,9 persen calon perempuan. Sementara pada pilkada serentak 2017 tercatat hanya 7.1 persen perempuan dari total calon kepala daerah/wakil kepala daerah yang bertarung

Proses demokratisasi tersebut merupakan alternatif bagi developmentalism karena pada kenyataannya merupakan perwujudan sistem yang secara ekonomi, yang sesungguhnya sangat otoriter dan eksploitatif, secara politik sangat represif dan secara kultural melahirkan dominasi. Jadi demokratisasi merupakan satu-satunya cara dan proses yang memungkinkan terciptanya ruang kesempatan, wewenang dan memungkinkan rakyat mengelola dirinya sendiri melalui diskusi dan aksi bersama, dengan prinsip persamaan dan keadilan. Demokratisasi akan terjadi jika memang masyarakat sendiri mengidamkan dan mencita-citakan perjuangannya (Fakih, 2013: 165).

Asghar Ali Engineer menyebutkan bahwa kesetaraan status yang merupakan implikasi dari nilai keadilan antara lakilaki dan perempuan tercermin pada dua hal. Pertama, dalam pengertiannya yang umum, kesetaraan status berarti penerimaan martabat kedua jenis kelamin dalam ukuran yang setara (sederajat). Kedua, laki-laki dan perempuan memiliki hak-hak yang setara dalam bidang sosial politik. Keduanya memiliki hak yang setara untuk mengadakan perkawinan atau memutuskannya, keduanya memiliki hak yang sama untuk mengatur hak miliknya tanpa campur tangan yang lain. Keduanya juga bebas memilih profesi atau cara hidup, memilki kesetaraan dalam tanggungjawab sebagimana memiliki kesetaraan dalam kebebasan (Engineer, 1994).

Menurut Abdul Mustaqim, kesetaraan dan keadilan gender memiliki implikasi pada beberapa hal. Pertama, bahwa kesetaraan dan keadilan gender meniscayakan tidak adanya salah satu jenis kelamin yang tersubordinasi oleh jenis kelamin yang lain. Kedua, tidak ada marginalisasi terhadap jenis kelamin tertentu dengan mengurangi kesempatannya. Ketiga, terbebaskan dari stereo type yang sesungguhnya hanya merupakan mitos belaka. Keempat, tidak ada yang menanggung beban lebih berat dari yang lain. Dalam kaitan ini keadilan gender 
meniscayakan kesamaan kepada laki-laki dan perempuan, baik dalam hal hak dan kewajibannya.

\section{SIMPULAN}

Dari paparan yang telah penulis tuliskan pada bagian terdahulu, maka dapat disimpulan beberapa (meskipun paper ini merupakan awal pemikiran kritis penulis dengan menggunakan metode pendekatan Islamic Studies). Pertama kontekstualisasi wacana feminisme dalam Islam dengan membaca ulang teks-teks ayat dalam Al-Quran yang misoginis dalam prakteksnya mengalami kompleksitas dan jalan yang tidak mudah. Hal ini ditandai dengan kedudukan otoritas atas tafsir teks Al-Quran dan hadits-hadits yang merugikan perempuan. Kondisi moderenitas Islam tidak sejalan dengan ruang tafsir yang dubuka, itu sebabnya jika hal itu dibendung dan digagalkan maka keniscayaan yaang akan terjadi, yakni Islam semakin di tinggalkan karena bersifat rigid dan kaku dalam merespon perkembangan zaman. Kedua, akar historis perkembangan feminisme di dunia, tidak dapat dilepaskan dari sejarah gerakan feminisme modern yang dimulai pada tahun 1960 dan dipelopori oleh kaum perempuan intelektual di Amerika Serikat.

Adapun perkembangan feminisme di Indonesia terjadi sangat lamban sejalan dengan negara-negara muslim. Perkembangan feminisme sebagai ideologi dan alat gerakan, di negara-negara Timur Tengah, mengalami kecenderungan perkembangan yang sulit, kondisi tersebut disebabkan oleh masih adanya aturanaturan Islam yang mereka anggap kaku dan menjerat perempuan. Realitas lain adalah masih terjadinya kasus tindak kekerasan yang menimpa perempuan, kecilnya ruang partisipasi perempuan di sektor politik dan publik. Feminisme sebagai alat analisis maupun gerakan selalu bersifat historis dan kontekstual, artinya muncul sebagai jawaban atas masalah-masalah perempuan yang aktual dan kontekstual. Karena itu, "lokalitas" sangat menjadi pertimbangan sebab perempuan tidak bisa dilihat sebagai satu atau monolitik. 


\section{DAFTAR PUSTAKA}

Arivia, Gadis. 2005. Feminsme Sebuah Kata Hati (Postkolonialisme dan Feminisme;

Dimana Kartini?). Jakarta: Kompas Publishing.

Badran. 2002. "Islamic Feminism: What's in a Name?" Al-Ahram Weekly Online, no. 569, Al-Ahram Organization.

Catatan Tahunan Komnas Perempuan Tahun 2017

Cooke, Miriam. 2003. Women Claim Islam, 61. January 27.

Djoeffan, Sri Hidayati. 2001. Gerakan Feminisme Di Indonesia : Tantangan Dan Strategi Mendatang. Jurnal Mimbar. No. 3 Th.XVI.

El Sadawi, Nawal dan Hibah Rauf Izzat. 2000. Perempuan, Agama, dan Moralitas

Antara Nalar Feminis dan Nalar Revivalis. Jakarta: Erlangga.

El Sadawi, Nawal. 2011. Perempuan Dalam Budaya Patriarki. Yogyakarta: Pustaka Pelajar.

Engineer, Asghar Ali. 1994. Hak-hak Perempuan dalam Islam. Yogyakarta: Yayasan Bentang Budaya

Fakih, Mansour. 1997. Analisis Gender dan Transformasi Sosial. Yogyakarta:

Pustaka Pelajar.

Gerung, Rocky. 2016. Pedagogi Feminis: Suatu Posisi Politik. Jurnal Perempuan. Volume. 21 No. 3.

Gould, Carol C. dan Marx W. Wartofsky, ed. 1975. Women and Philosophy: Toward a Theory of Liberation. New York: GPPS.

Gottlieb. 1993. Radical Philosopy; Tradition, Counter-Tradition, Politics. Philadelphia: Temple University Press.

Hidayatullah, Syarif. 2010. Teologi Feminisme Islam. Yogyakarta: Pustaka Pelajar. Kadarusman. 2005. Agama relasi gender dan feminism. Yogyakarta: Kreasi Wacana. 
Karim, Abdul. 2014. Kerangka Studi Feminisme (Model Penelitian Kualitatif Tentang Perempuan Dalam Koridor Sosial Keagamaan). Jurnal Fikrah. Volume 2, No 1.

Konvensi International Labour Organization No.189 tentang Pekerjaan Layak bagi Pekerja Rumah Tangga, 2011.

McAlister. 1996. Hypatia's Daughter; Fifteen Hundred Years of Woman Philosophers. Bloomington: Indiana University Press.

Mustaqim, Abdul. 1999 "Feminisme dalam Perspektif Riffat Hassan". Tesis. S2 Program Pasca Sarjana IAIN Sunan Kalijaga Yogyakarta.

Muslih, Mohammad. 2007. Bangunan Wacana Gender. Ponorogo: CIOS

Nasution, Khoirudin. 2002. Fazlur Rahman Tentang Wanita. Yogyakarta: TazzafaAcademia.

Stowasser, Barbara. 1998. Gender Issues and Contemporary Quran Interpretation

Islam. Gender, and social Change, Edited by Yvonne Yazbeck Haddad.

Oxford: Oxford University Press.

Syahrur, Muhammad. 2007. Prinsip dan Dasar Hermeneutika Hukum Islam Kontemporer. Yogyakarta: ElsaQ Press.

Tucker, Judithh E. 2008. Women, Family and Gender In Islamic Law. Cambridge: Cambridge University Press.

Umar, Nasarudin. 1999. Argumen Kesetaraan Gender Perspektif Al-Quran. Jakarta: Paramadina.

Wadud, Amina. 1999. Qur'an And Woman. Oxford: Oxford University Press. 